\title{
Buffered versus unbuffered local anesthesia for inferior alveolar nerve block injections in children: a systematic review
}

\author{
Sunny Priyatham Tirupathi', Srinitya Rajasekhar ${ }^{2}$ \\ 1Department of Pedodontics \& Preventive Dentistry, Malla Reddy Institute of Dental Sciences, Hyderabad Telangana, India \\ 2Department of Pedodontics \& Preventive Dentistry, Malla Reddy Dental College for Women, Hyderabad, Telangana, India
}

\begin{abstract}
Background: The present study aimed to evaluate and compare the efficacy of buffered and unbuffered local anesthesia solutions during inferior alveolar nerve block (IANB) administration in children.

Methods: PubMed, Ovid SP, and Cochrane databases were searched separately by two independent reviewers for potential papers published between 1980 and April 2020 using relevant MeSH terms and pre-specified inclusion and exclusion criteria. T Studies of IANB administration in children comparing buffered and unbuffered local anesthesia solutions were evaluated. The primary outcome evaluated was pain (perception and reaction), while the secondary outcome was the onset of anesthesia.

Results: A total of five articles were included in a qualitative analysis; among them, four qualified for quantitative analysis of the primary outcome and three for quantitative analysis of the secondary outcome. A fixed-effects model was used to perform the meta-analysis.

Pain perception (child-reported pain): Significantly lower pain scores were reported with buffered local anesthesia solution than with unbuffered solution ( $\mathrm{P}=0.006$, MD: $-0.32,95 \% \mathrm{CI}$ : -0.55 to -0.09$)$.

Pain reaction (observer-reported pain reaction in child): No significant difference was found between buffered and unbuffered solution in terms of observer-reported pain behavior in the child $(\mathrm{P}=0.09$, MD: $-0.21,95 \%$ CI: -0.46 to 0.04$)$.

Onset of anesthesia: A significantly lower duration of anesthesia onset was reported with buffered local anesthesia solution than with unbuffered solution ( $\mathrm{P}=0.00001, \mathrm{MD}:-12.38,95 \% \mathrm{CI}$ : -17.64 to -7.13 ].

Conclusion: Buffering local anesthesia solution may reduce discomfort due to IANB injection administration and lower the initial onset time of anesthesia. More randomized control trials with adequate sample sizes should be carried out to validate the accuracy of these results.
\end{abstract}

Keywords: Buffering; Children; Inferior Alveolar Nerve; Local Anesthesia; Pain.

This is an Open Access article distributed under the terms of the Creative Commons Attribution Non-Commercial License (http://creativecommons.org/licenses/by-nc/4.0/) which permits unrestricted non-commercial use, distribution, and reproduction in any medium, provided the original work is properly cited.

\section{INTRODUCTION}

Most commercially available local anesthetic (LA) solutions used in dentistry are acidic $\left(\mathrm{pH}: 3.5^{-5}\right)$, as manufacturers provide the solutions as hydrochloride salts to improve solubility, stability, and consequently shelf life [1]. Furthermore, LA solution with vasoconstrictor is more acidic than that without [2]. Injecting such acidic LA solution disrupts the local tissue $\mathrm{pH}$ for a prolonged period. This effect can be aggravated when an LA solution with a vasoconstrictor is used, resulting in

Received: July 10, 2020 - Revised: August 5, 2020 - Accepted: August 13, 2020

Corresponding Author: Sunny Priyatham Tirupathi, Department of Pedodontics \& Preventive Dentistry, Malla Reddy Institute of Dental Sciences, Hyderabad Telangana, India.

E-mail: dr.priyatham@gmail.com

Copyright(c) 2020 Journal of Dental Anesthesia and Pain Medicine 
burning sensation and pain [1].

LA solutions are not stable at alkaline $\mathrm{pH}$, so no such solutions are manufactured commercially. For this reason, most researchers recommend buffering the LA solution using sodium bicarbonate just before injection. The concept of buffering LA before injection is not new, nor is the use of buffered LA solutions in dentistry. However, only a few studies focused on this topic from 1967 to 2010 [1,3-8]. From 2010 to 2015, the number of studies increased slowly [9-15], reaching a peak between 2016 and 2020.

Three systematic reviews have focused on LA buffering in adults [16-18]: Aulestia-Viera et al. in 2018 [17] reported that buffered LA solutions showed no superiority over unbuffered in terms of either reported pain or onset of anesthesia; however, two other systematic reviews reported that buffered LA solutions were better than unbuffered in both outcomes $[16,18]$.

To our knowledge, no systematic reviews have evaluated the efficacy of buffered and unbuffered LA solutions in children. The aim of the present systematic review was to compare the efficacy of buffered LA solution with that of unbuffered LA solution during inferior alveolar nerve block (IANB) administration in children.

\section{METHODS}

\section{Protocol}

The present study followed the PRISMA (Preferred Reporting Items for Systematic Reviews and MetaAnalyses) guidelines for reporting.

\section{Eligibility criteria}

The search strategy was conducted using the PICO framework (population, intervention, comparison, and outcome), based on the following question: "Does buffering of local anesthesia improve the comfort and success rate of inferior alveolar nerve block (IANB) injections in children." The PICO search strategy was as follows: population, children between 4 and 16 years; intervention, buffered LA when used for IANB only; comparison, unbuffered LA when used for IANB only; outcome of interest, injection pain and onset of anesthesia.

An electronic search was performed in three databases: PubMed, Ovid SP, and Cochrane. The search was conducted across publication years 1980 to 2020 . The last search was performed on 30 April, 2020. Only articles published in English were included. The search was based on a pre-specified broad question using relevant $\mathrm{MeSH}$ terms. ((buffering) AND (local anesthesia)) AND (dental)

\section{Eligibility criteria}

Randomized controlled clinical trials that compared buffered to unbuffered LA for IANB injections in children were included. Non-randomized studies, non-controlled clinical trials, comparative studies, technical notes, case reports, narrative reviews, and systematic reviews and articles that could not be translated into English were excluded. Initially, studies retrieved after the comprehensive MeSH terms search were imported to Zotero (www.zotero.org) from all the databases. Duplicates were excluded and the titles and abstracts were screened. Potential articles were then included for a full text review.

The data were analyzed by two independent reviewers and recorded on Excel. The data form contained information regarding author names and year of publication, study design, number of participants, age, intervention, control, and outcomes. The primary outcome measure sought for was "pain during IANB administration." The secondary outcome was "onset of anesthesia."

\section{Data synthesis}

A qualitative analysis of the selected studies was carried out and a quantitative meta-analysis was performed using RevMan software. 
Table 1. Excluded studies with reasons

\begin{tabular}{cll}
\hline Sno & \multicolumn{1}{c}{ Excluded articles } & Reasons for exclusion \\
\hline 1. & Senthoor et al. 2020.[19] & Study carried out in adults. \\
2. & Warren et al. 2017.[20] & Study carried out in adults. \\
3. & Phero et al. 2017.[21] & Study carried out in adults. \\
4. & Shurtz et al. 2015.[9] & Study carried out in adults. \\
5. & Saatchi et al. 2015.[10] & Study carried out in adults. \\
6. & Commerci et al. 2015.[11] & Study carried out in adults. \\
7. & Kashyap et al. 2011.[15] & Study carried out in adults. \\
8. & Whitcomb et al. 2010.[3] & Study carried out in adults. \\
9. & Ridenour et al. 2001.[4] & Study carried out in adults. \\
\hline
\end{tabular}
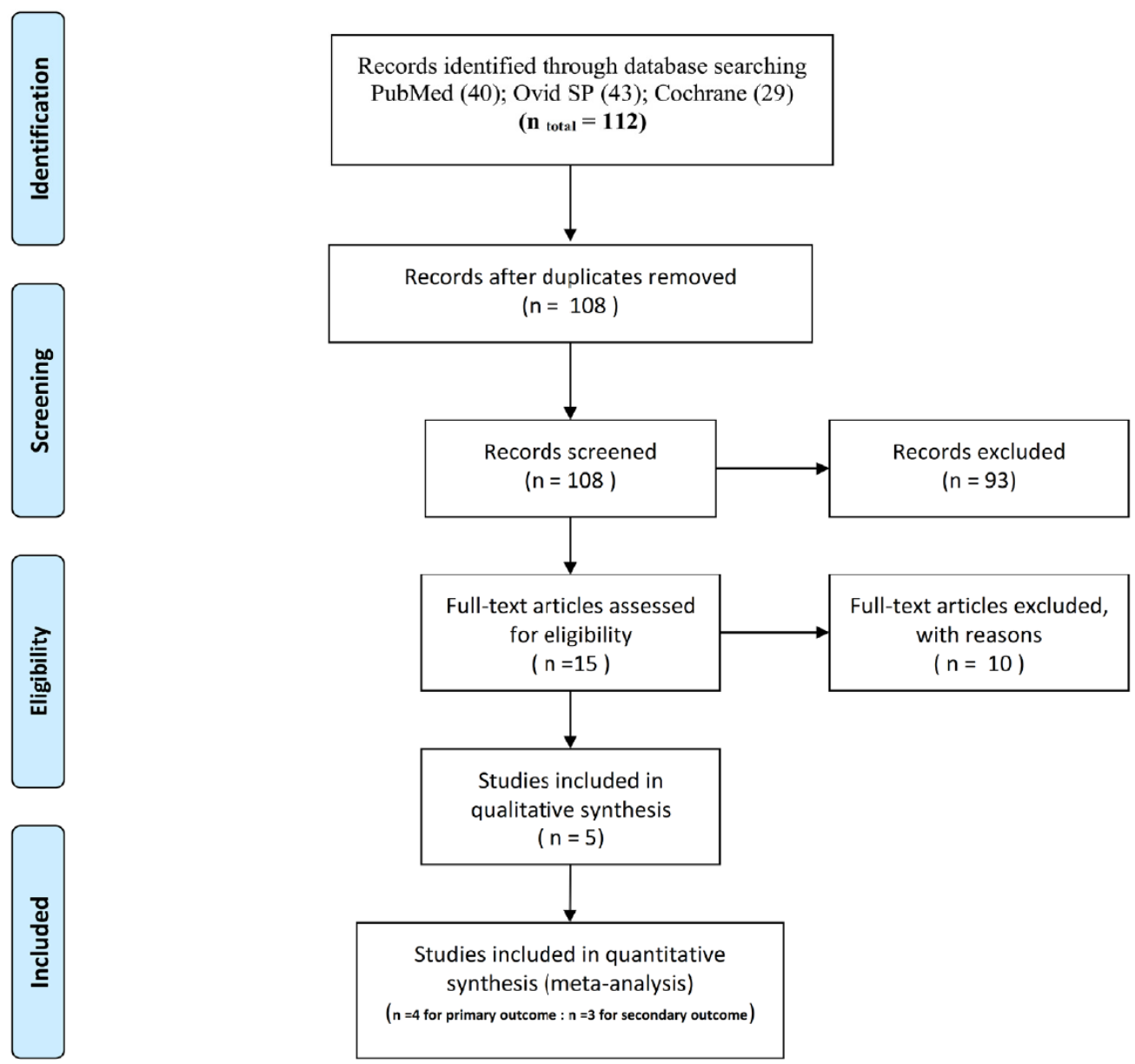

Fig. 1. PRISMA 2009 flow diagram word

\section{Risk of bias assessment}

A methodological quality assessment of the included articles was conducted independently by two review team members using the Cochrane collaboration's criteria. Risk of bias was evaluated for all seven parameters: sequence generation, allocation concealment, blinding of parti- cipants and personnel, blinding of outcome assessment, completeness of outcome data, selective reporting of outcomes, and other sources of bias. If one or more domains presented a high risk of bias, the studies were categorized as having a high risk of bias. Studies with seven domains of low-bias risk were classified into the low risk of bias group. 
Table 2. Characteristics of included studies

\begin{tabular}{|c|c|c|c|c|c|c|c|c|c|c|c|}
\hline $\begin{array}{l}\text { Author } \\
\text { (year) }\end{array}$ & Study design & Sample & $\begin{array}{l}\text { Reason for } \\
\text { IANB } \\
\text { admini- } \\
\text { stration }\end{array}$ & $\begin{array}{c}\text { Topical } \\
\text { anesthe- } \\
\text { sia used } \\
\text { before } \\
\text { IANB. }\end{array}$ & $\begin{array}{l}\text { Intervention } \\
\text { and comparison } \\
\text { groups }\end{array}$ & $\begin{array}{c}\text { Buffering } \\
\text { agent }\end{array}$ & $\mathrm{pH}$ & $\begin{array}{l}\text { Buffering } \\
\text { method }\end{array}$ & Mean \pm SD & $\begin{array}{l}\text { Pain perception } \\
\text { (self-reported pain by } \\
\text { the child) } \\
\text { Mean } \pm S D\end{array}$ & $\begin{array}{c}\text { Pain Reaction } \\
\text { (observer reported } \\
\text { pain reaction) } \\
\text { Mean } \pm \text { SD }\end{array}$ \\
\hline $\begin{array}{l}\text { Meincken } \\
\text { et al. } 2019 \\
\text { [22] }\end{array}$ & $\begin{array}{l}\text { Randomized } \\
\text { split-mouth } \\
\text { cross-over } \\
\text { trial }\end{array}$ & $\begin{array}{l}65 \\
\text { children } \\
\text { Aged } \\
7-11 \\
\text { years }\end{array}$ & $\begin{array}{l}\text { Extrac- } \\
\text { tions, } \\
\text { resto- } \\
\text { rations }\end{array}$ & $\begin{array}{l}20 \% \\
\text { benzo- } \\
\text { caine }\end{array}$ & $\begin{array}{l}\text { 130 IANB } \\
\text { injections divided } \\
\text { into two groups } \\
\text { G1: 67-unbuffered } \\
\text { 2\% lignocaine with } \\
\text { epinephrine } \\
\text { G2: 63-Buffered }\end{array}$ & $\begin{array}{l}\text { Sodium } \\
\text { bicarbonate } \\
\text { 9:1 ratio }\end{array}$ & $\begin{array}{l}\text { Unbuffered } \\
3.85 \\
\text { Post- } \\
\text { buffer } 7.21\end{array}$ & $\begin{array}{l}\text { Onpharma } \\
\text { mixing pen }\end{array}$ & $\begin{array}{l}\text { No significant } \\
\text { difference in } \\
\text { onset time } \\
\text { between } \\
\text { unbuffered } \\
\text { (151.8 } \pm 62.4 \mathrm{~s} \text { ) } \\
\text { and buffered } \\
\text { lidocaine } \\
\text { (133.2 } \pm 54 \mathrm{~s} \text { ) } \\
\text { anesthetic } \\
\text { solutions } \\
\text { (P=0.052) }\end{array}$ & $\begin{array}{l}\text { Measured using } \\
\text { WB-FPS. No significant } \\
\text { difference in } \\
\text { self-reported pain } \\
\text { between unbuffered } \\
(1.6 \pm 2.05) \text { and } \\
\text { buffered lidocaine } \\
(1.11 \pm 1.32) \\
\text { anesthetic solutions } \\
(P=0.113)\end{array}$ & $\begin{array}{l}\text { Measured using } \\
\text { t OSUBRS. No } \\
\text { significant difference } \\
\text { in observed pain } \\
\text { between unbuffered } \\
(1.76 \pm 1.11) \text { and } \\
\text { buffered lidocaine } \\
(1.52 \pm 0.98) \\
\text { anesthetic solutions } \\
(P=0.201)\end{array}$ \\
\hline $\begin{array}{l}\text { Afsal et al. } \\
2019 \text { [23] }\end{array}$ & $\begin{array}{l}\text { Rando-mized, } \\
\text { double-blind } \\
\text { cross-over } \\
\text { design }\end{array}$ & $\begin{array}{l}48 \\
\text { children } \\
\text { aged } \\
5-10 \\
\text { years }\end{array}$ & $\begin{array}{l}\text { Pulp } \\
\text { therapy } \\
\text { extractions }\end{array}$ & $\begin{array}{l}20 \% \\
\text { benzo- } \\
\text { caine }\end{array}$ & $\begin{array}{l}96 \text { IANB injections } \\
\text { block randomized } \\
\text { into three groups. } \\
\text { G1: unbuffered } \\
\text { lignocaine- } 2 \% \\
\text { lignocaine } \\
\text { hydro-chloride } \\
\text { with 1:200,000 } \\
\text { epinephrine } \\
\text { G2: buffered } \\
\text { lignocaine- } 2 \% \\
\text { lignocaine } \\
\text { hydro-chloride } \\
\text { with 1:200,000 } \\
\text { epinephrine } \\
\text { G3: unbuffered } \\
\text { articaine-4\% } \\
\text { articaine with } \\
\text { 1:200,000 } \\
\text { epinephrine }\end{array}$ & $\begin{array}{l}\text { Sodium } \\
\text { bicarbonate } \\
\text { 10:1 ratio }\end{array}$ & $\begin{array}{l}\text { Unbuffered } \\
4.33 \\
\text { Post-buffer } \\
7.32\end{array}$ & $\begin{array}{l}\text { Manual } \\
\text { mixing in the } \\
\text { vial }\end{array}$ & $\begin{array}{l}\text { Significant } \\
\text { difference in } \\
\text { onset time } \\
\text { between } \\
\text { unbuffered } \\
(73.63 \pm 13.5 \\
\text { s) and buffered } \\
\text { lidocaine } \\
\text { (60.00 } \pm 10.4 \\
\text { s) anesthetic } \\
\text { solutions } \\
(P<0.001)\end{array}$ & $\begin{array}{l}\text { Measured using } \\
\text { WB-FPS } \\
\text { Significant } \\
\text { difference in } \\
\text { self-reported pain } \\
\text { between unbuffered } \\
(3.2 \pm 1.059) \text { and } \\
\text { buffered lidocaine } \\
(2.54 \pm 1.352) \\
\text { anesthetic solutions } \\
(P<0.001)\end{array}$ & $\begin{array}{l}\text { Measured with (SEM) } \\
\text { No significant } \\
\text { difference in observed } \\
\text { pain between } \\
\text { unbuffered } \\
(2.0 \pm 0.075) \text { and } \\
\text { buffered } \\
\text { lidocaine } \\
(1.97 \pm 0.157) \\
\text { anesthetic solutions } \\
(P=0.68)\end{array}$ \\
\hline $\begin{array}{l}\text { Kurien et al. } \\
2018 \text { [24] }\end{array}$ & $\begin{array}{l}\text { Randomized, } \\
\text { split-mouth, } \\
\text { clinical trial }\end{array}$ & $\begin{array}{l}60 \\
\text { children } \\
\text { aged } \\
6-12 \\
\text { years }\end{array}$ & $\begin{array}{l}\text { Pulp } \\
\text { therapy }\end{array}$ & $\begin{array}{l}\text { Not } \\
\text { mentioned }\end{array}$ & $\begin{array}{l}120 \text { IANB } \\
\text { injections block } \\
\text { randomized into } \\
\text { three groups } \\
\text { G1: unbuffered } \\
\text { lignocaine. 2\% } \\
\text { lignocaine } \\
\text { hydrochloride } \\
\text { with 1:200,000 } \\
\text { epinephrine } \\
\text { G2: buffered } \\
\text { lignocaine } 2 \% \\
\text { lignocaine } \\
\text { hydrochloride } \\
\text { with 1:200,000 } \\
\text { epinephrine } \\
\text { G3: pre-warmed } \\
2 \% \text { lignocaine with } \\
\text { 1:200,000 } \\
\text { epinephrine }\end{array}$ & $\begin{array}{l}\text { Sodium } \\
\text { bicarbonate } \\
\text { 10:1 ratio }\end{array}$ & $\begin{array}{l}\text { Not } \\
\text { mentioned }\end{array}$ & $\begin{array}{l}\text { Manual } \\
\text { mixing }\end{array}$ & $\begin{array}{l}\text { Significant } \\
\text { difference in } \\
\text { onset time } \\
\text { between } \\
\text { unbuffered } \\
\text { (150 s) and } \\
\text { buffered } \\
\text { lidocaine } \\
\text { (120 s) } \\
\text { anesthetic } \\
\text { solutions } \\
(\mathrm{P}=0.001)\end{array}$ & Not measured & $\begin{array}{l}\text { SEM scales evaluated } \\
\text { separately. Significant } \\
\text { difference in SEM } \\
\text { scale score between } \\
\text { buffered and } \\
\text { unbuffered lignocaine } \\
(P=0.028,0.013 \text {, } \\
0.02)\end{array}$ \\
\hline
\end{tabular}




\begin{tabular}{|c|c|c|c|c|c|c|c|c|c|c|c|}
\hline $\begin{array}{l}\text { Chopra et } \\
\text { al. 2016 } \\
\text { [25] }\end{array}$ & $\begin{array}{l}\text { Rando-mized } \\
\text { double blind } \\
\text { split mouth } \\
\text { crossover } \\
\text { trial. }\end{array}$ & $\begin{array}{l}30 \\
\text { children } \\
\text { aged } \\
6-12 \\
\text { years }\end{array}$ & $\begin{array}{l}\text { Not } \\
\text { mentioned }\end{array}$ & $\begin{array}{l}\text { Not } \\
\text { mentioned }\end{array}$ & $\begin{array}{l}60 \text { IANB injections } \\
\text { divided into two } \\
\text { groups } \\
\text { G1: unbuffered 2\% } \\
\text { lignocaine with } \\
\text { epinephrine } \\
\text { G2: Buffered 2\% } \\
\text { lignocaine with } \\
120,000 \\
\text { epinephrine. }\end{array}$ & $\begin{array}{l}\text { Sodium } \\
\text { bicarbonate. } \\
\text { 10:1 ratio }\end{array}$ & $\begin{array}{l}\text { Unbuffered } \\
4.33 \\
\text { Post-buffer } \\
7.32\end{array}$ & $\begin{array}{l}\text { Manual } \\
\text { mixing }\end{array}$ & $\begin{array}{l}\text { No significant } \\
\text { difference in } \\
\text { onset time } \\
\text { between } \\
\text { unbuffered } \\
(86 \pm 27.8 \mathrm{~s}) \\
\text { and buffered } \\
\text { lidocaine } \\
(84.2 \pm 28.9 \mathrm{~s}) \\
\text { anesthetic } \\
\text { solutions } \\
(\mathrm{P}=0.0824)\end{array}$ & $\begin{array}{l}\text { Measured using } \\
\text { HP-VAS } \\
\text { No significant } \\
\text { difference in } \\
\text { self-reported pain } \\
\text { between unbuffered } \\
(39.5 \pm 18.2) \text { and } \\
\text { buffered } \\
\text { lidocaine (36.8 } \pm 17.7) \\
\text { anesthetic solutions } \\
(P=0.93)\end{array}$ & $\begin{array}{l}\text { Measured with (SEM) } \\
\text { No significant } \\
\text { difference in observed } \\
\text { pain between } \\
\text { unbuffered } \\
(4.84 \pm 1.8) \text { and } \\
\text { buffered } \\
\text { lidocaine } \\
(4.60 \pm 1.57) \\
\text { anesthetic solutions } \\
(P=0.71)\end{array}$ \\
\hline $\begin{array}{l}\text { Tavana et } \\
\text { al. } 2013 \\
\text { [26] }\end{array}$ & $\begin{array}{l}\text { double- } \\
\text { blind, } \\
\text { randomized, } \\
\text { cross-over } \\
\text { trial }\end{array}$ & $\begin{array}{l}20 \\
\text { children } \\
\text { aged } \\
9-12 \\
\text { years. }\end{array}$ & $\begin{array}{l}\text { Not } \\
\text { mentioned }\end{array}$ & $\begin{array}{l}\text { Not } \\
\text { mentioned }\end{array}$ & $\begin{array}{l}40 \text { IANB injections } \\
\text { were divided into } \\
\text { two groups } \\
\text { G1: unbuffered 2\% } \\
\text { lignocaine with } \\
\text { 100,000 } \\
\text { epinephrine } \\
\text { G2: Buffered 2\% } \\
\text { lignocaine with } \\
\text { 100,000 } \\
\text { epinephrine }\end{array}$ & $\begin{array}{l}\text { Sodium } \\
\text { bicarbonate }\end{array}$ & $\begin{array}{l}\text { Not } \\
\text { mentioned }\end{array}$ & Onset $^{\mathrm{TM}}$ & Not measured & $\begin{array}{l}\text { Measured using } \\
\text { VAS } \\
\text { No significant } \\
\text { difference in } \\
\text { self-reported pain } \\
\text { between unbuffered } \\
(43 \pm 27.01) \text { and } \\
\text { buffered } \\
\text { lidocaine } \\
(33.05 \pm 24.80) \\
\text { anesthetic solutions } \\
(\mathbb{P}=0.23)\end{array}$ & Not measured \\
\hline
\end{tabular}

*Abbreviations: WB-FPS, Wong Baker FACES scale; VAS, visual analog scale; HP-VAS, Heft-Parker visual analog scale; OSUBRS, Ohio State University Behavior Rating Scale; SEM scale, sound, eye, and motor scale; G1, group 1; G2, group 2; G3, group 3

\section{RESULTS}

Across all databases, 112 records were found, of which four were duplicates; 108 records were screened by title and abstract. The full texts of 15 potentially relevant papers were evaluated, among which 10 were excluded [3,4,7,9-11,15,19-21] for reasons presented in Table 1. Ultimately, five studies were included in the final systematic review [22-26]. Figure 1 shows a flowchart of the search results.

\section{Characteristics of included studies}

The characteristics of the included studies are presented in Table 2. All five studies were published between 2013 and 2019 and followed a randomized, split-mouth, crossover design. Risk of bias (Fig. 2) was evaluated according to the Cochrane guidelines and randomization was mentioned in all the studies $(\mathrm{n}=5)$. The method of allocation concealment was not mentioned in two studies [22,24]. Blinding of both participants and personnel was performed in three studies [23-25]. Blinding of outcome assessment was performed in all five

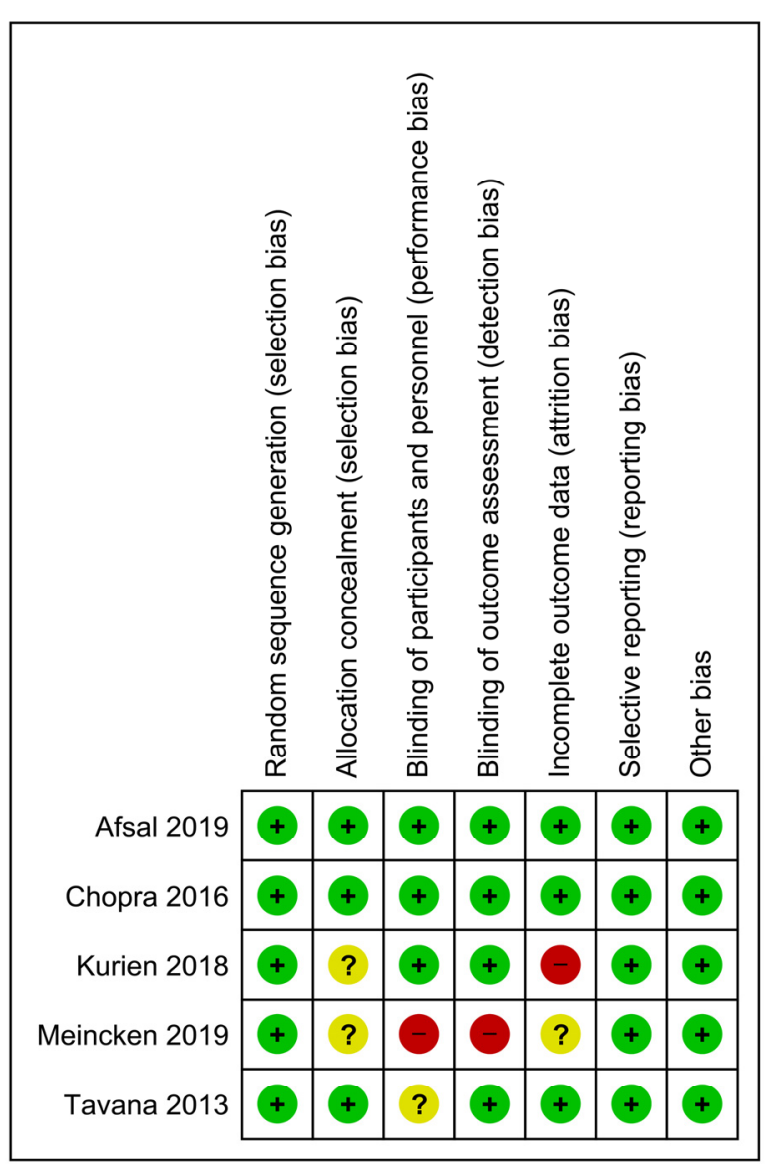

Fig. 2. Risk of bias summary 
studies. Attrition bias was reported in only one study [24]. Bias due to selective reporting was not observed in any of the included studies.

\section{DISCUSSION}

All five studies were included in the final review; they followed a split-mouth, crossover design [22-26]. Four studies followed double blinding [23-26], and one study reported single blinding [22]. The age of the children reported in the included studies ranged from 5 to 12 years (the included age range was 4-16 years).

Our systematic review only included studies that compared buffered and unbuffered LA solutions for IANB injections in children. In all five studies, sodium bicarbonate solution was used to buffer the local anesthetic solution prior to injection. The dilution ratio was 10:1 in three studies, 9:1 in the study by Meincken et al. [22] in 2019, and not mentioned in the study by Tavana et al. [26] in 2013. The main aim of buffering the LA was to raise the $\mathrm{pH}$ of the solution. In the included studies, the $\mathrm{pH}$ of unbuffered LA solutions ranged from 3.85 to $4.33[22,23,25]$. The $\mathrm{pH}$ of buffered LA solution in most of the studies was 7.22 or 7.32 [22,23,25]. A manual buffering method was used in three studies [23-25], whereas the Onset ${ }^{\mathbb{R}}$ mixing pen (Onpharma Co, Nevada, USA) was used in two studies $[22,26]$. The primary outcome evaluated was "pain during IANB administration in children receiving buffered and unbuffered LA solutions."

\section{Pain perception (child-reported pain)}

Four studies evaluated child-reported pain scores $[22,23,25,26]$, but measurement scales differed. The Wong-Baker faces pain scale (WB-FPS) was used in two studies, the conventional visual analog scale was used in the study by Tavana et al. in 2013, and the Heft-Parker visual analog scale was used in the study by Chopra et al. in 2016. Among the four studies that compared child-reported pain perception of buffered and unbuffered
LA for IANB, only the study by Afsal et al. in 2019 reported significantly lower pain scores with buffered solution (WB-FPS score: $2.54 \pm 1.35$ ) than with unbuffered solution (WB-FPS score: $3.2 \pm 1.05$; $\mathrm{P}<$ 0.001) [23]. The remaining three studies reported no significant difference between the buffered and unbuffered solutions (Meincken 2019: buffered solution WB-FPS score, $1.11 \pm 1.32$; unbuffered solution WB-FPS score, $1.6 \pm 2.05 ; \mathrm{P}=0.11$; Chopra 2016: buffered solution HP-VAS score, $36.8 \pm 17.7$; unbuffered solution HP-VAS score, $39.5 \pm 18.2 ; \mathrm{P}=0.93$; Tavana 2013: buffered solution VAS score, $33.05 \pm 24.80$; unbuffered solution VAS score, $43 \pm 27.01 ; \mathrm{P}=0.23)[22,25,26]$.

\section{Quantitative data analysis}

As different measurement scales were used (WB-FPS in two studies, HP-VAS in one study, and VAS in one study), child-reported pain perception varied among the four studies, so standardized mean difference was used as a summary statistic to pool the data in the meta-analysis. The fixed-effects model revealed significantly lower pain scores with buffered solution than with unbuffered solution ( $\mathrm{P}=0.006$, $\mathrm{MD}$ : $-0.32,95 \% \mathrm{CI}$ : -0.55 to -0.09 ; Fig. 3 ).

\section{Pain reaction (observer-reported pain reaction in children)}

Four studies evaluated observer-reported pain behavior in children during IANB injections with buffered or unbuffered LA solutions [22-25]. Three studies reported no significant difference in the observer reported pain behavior between buffered and unbuffered solutions (Meincken 2019: buffered solution OSUBRS score, 1.52 \pm 0.98 ; unbuffered solution OSUBRS score, $1.76 \pm 1.11$; $\mathrm{P}=0.20$; Chopra 2016: buffered solution SEM score, 4.60 \pm 1.57 ; unbuffered solution SEM score, $4.84 \pm 1.8$; P $=0.71$; Afsal 2019: buffered solution SEM score, 1.97 \pm 0.157; unbuffered solution SEM score, $2.0 \pm 0.075$; $\mathrm{P}=0.68)[22,23,25]$. In 2018, Kurien et al. reported significantly lower sound $(\mathrm{P}=0.028)$, eye $(\mathrm{P}=0.013)$, and motor $(\mathrm{P}=0.021)$ scores for buffered solution than 


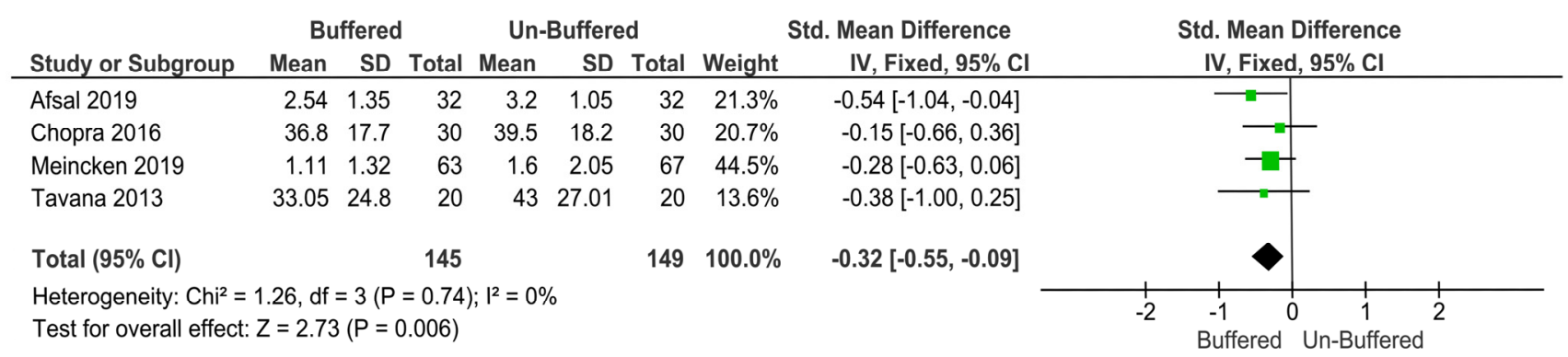

Fig. 3. The fixed-effects model revealed significantly lower pain scores with buffered solution than with unbuffered solution.

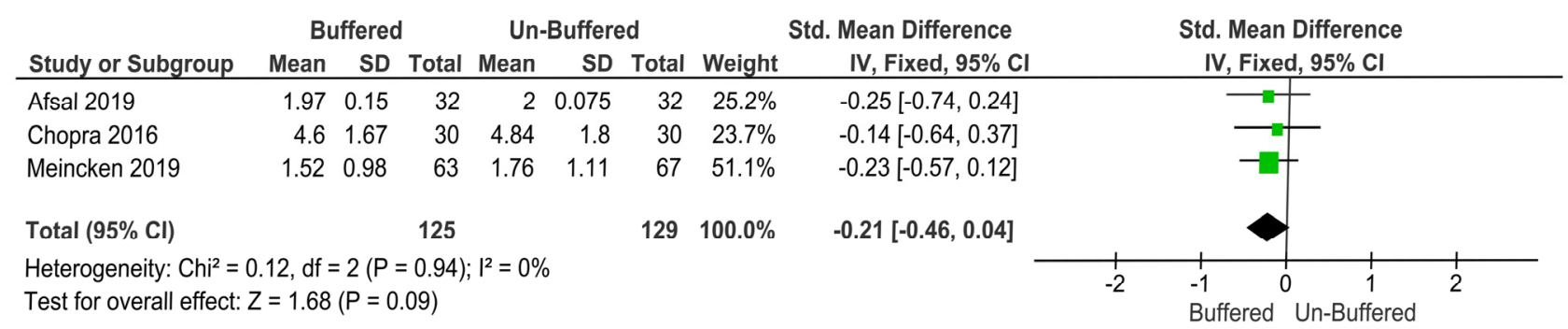

Fig. 4. The fixed-effects model reported no significant difference between the buffered and unbuffered solutions in terms of observer-reported pain behavior.

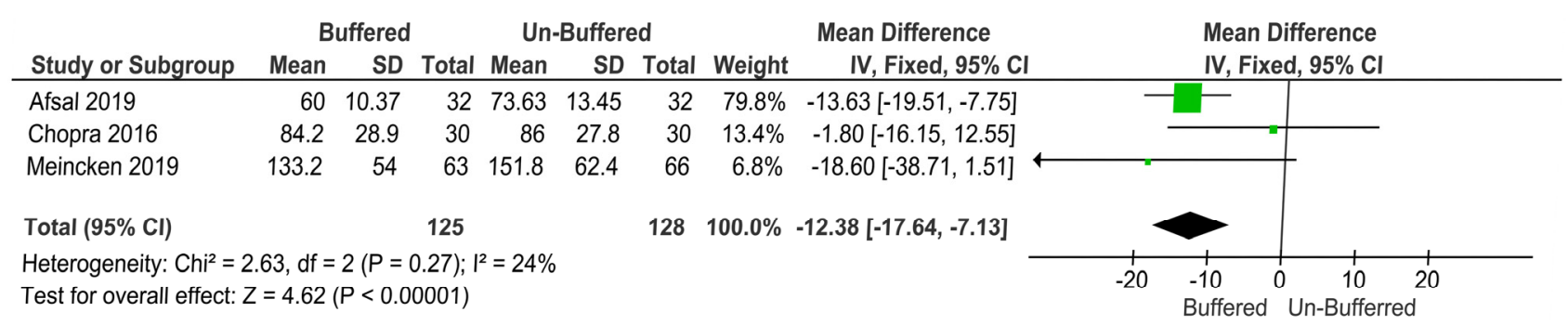

Fig. 5. The fixed-effects model reported a highly significant difference between the buffered and unbuffered solutions in terms of duration of onset of anesthesia.

for unbuffered solutions [24]. This study was excluded from the meta-analysis as the SEM scores were presented separately and no single score for the combined values was given.

\section{Quantitative data analysis}

Three studies were pooled in a meta-analysis of observer-reported pain behavior, out of which two used SEM and one used OSUBRS. Standardized mean difference was used as a summary statistic to pool the data in the meta-analysis. The fixed-effects model reported no significant difference between the buffered and unbuffered solutions in terms of observer-reported pain behavior ( $\mathrm{P}=0.09$, MD: $-0.21,95 \% \mathrm{CI}:-0.46$ to 0.04; Fig. 4).

\section{Onset time of anesthesia}

The secondary outcome- "onset time of anesthesia"was measured in four studies [22-25], of which two reported significantly lower onset time of anesthesia for buffered solutions (Afsal 2019: buffered solution onset time, 60.00 $\pm 10.37 \mathrm{~s}$; unbuffered solution onset time, $73.63 \pm 13.45 \mathrm{~s}$; $\mathrm{P}<0.001$; Kurien 2018: buffered solution onset time, $120 \mathrm{~s}$; unbuffered solution onset time, $150 \mathrm{~s} ; \mathrm{P}<0.001$ ) $[23,24]$. The other two studies reported no significant difference in the duration of onset of anesthesia between the buffered and unbuffered solutions (Meincken 2019: buffered solution onset time, $133.2 \pm 54$; unbuffered solution onset time, $151.8 \pm 62.4 \mathrm{~s}$; $\mathrm{P}=0.052$; Chopra 2018: buffered solution onset time, $84.2 \pm 28.9 \mathrm{~s}$; unbuffered solution onset time, $86 \pm 27.8 \mathrm{~s} ; \mathrm{P}=0.93)[22,25]$. 


\section{Quantitative data analysis}

The study by Kurien et al. in 2018 did not present the data properly, so it was excluded from the meta-analysis. Three studies were pooled for the secondary outcome onset time of anesthesia. The mean difference was used as a summary statistic to pool data in the meta-analysis. The fixed-effects model reported a highly significant difference between the buffered and unbuffered solutions in terms of duration of onset of anesthesia ( $\mathrm{P}=0.00001$, MD: $-12.38,95 \%$ CI: -17.64 to -7.13 ; Fig. 5).

\section{Limitations of this review}

A limited number of studies were available to pool data for meta-analysis. The study by Kurien et al. in 2018 had to be excluded from the quantitative analysis of observer-reported outcomes because the total SEM score was not provided; instead, the sound, eye, and motor scores were presented separately. Moreover, only mean values were provided for duration of anesthesia onset in that study; no standard deviations were provided [24].

\section{CONCLUSIONS}

Buffering LA solution may reduce discomfort due to IANB injection and lower the initial onset time of anesthesia after IANB administration in children. More randomized controlled trials with adequate sample sizes should be carried out to validate the accuracy of these results.

\section{AUHOR ORCLIDS}

Sunny Priyatham Tirupathi: https://orcid.org/0000-0002-2593-0090

Srinitya Rajasekhar: https://orcid.org/0000-0002-1498-1618

\section{AUHOR CONIRIBUIIONS}

Sunny Priyatham Tirupathi: Conceptualization, Data curation, Formal analysis, Methodology, Resources, Supervision, Writing - original draft, Writing - review \& editing

Srinitya Rajasekhar: Writing - review \& editing
DECLARATION OF INTEREST: There are no conflicts of interest to declare.

FUNDING: There is no financial support or sponsorship to declare.

\section{REFERENCES}

1. Rood JP. The use of buffered lignocaine solution in the presence of acute inflammation. J Dent 1977; 5: 128-30.

2. Frank SG, Lalonde DH. How acidic is the lidocaine we are injecting, and how much bicarbonate should we add? Can J Plast Surg 2012; 20: 71-3.

3. Whitcomb M, Drum M, Reader A, Nusstein J, Beck M. A prospective, randomized, double-blind study of the anesthetic efficacy of sodium bicarbonate buffered $2 \%$ lidocaine with 1:100,000 epinephrine in inferior alveolar nerve blocks. Anesth Prog 2010; 57: 59-66.

4. Ridenour S, Reader A, Beck M, Weaver J. Anesthetic efficacy of a combination of hyaluronidase and lidocaine with epinephrine in inferior alveolar nerve blocks. Anesth Prog 2001; 48: 9-15.

5. Courtney DJ, Agrawal S, Revington PJ. Local anaesthesia: To warm or alter the ph? a survey of current practice. J R Coll Surg Edinb 1999; 44: 167-71.

6. Primosch RE, Robinson L. Pain elicited during intraoral infiltration with buffered lidocaine. Am J Dent 1996; 9: $5-10$.

7. Crose VW. Pain reduction in local anesthetic administration through $\mathrm{pH}$ buffering. J Indiana Dent Assoc 1991; 70: 24-5.

8. Brennan PA, Morley MR, Langdon JD. A study of the effectiveness of dental $2 \%$ lignocaine local anaesthetic solution at different $\mathrm{pH}$ values. Br Dent J 1987; 163: 158-9.

9. Shurtz R, Nusstein J, Reader A, Drum M, Fowler S, Beck M. Buffered $4 \%$ articaine as a primary buccal infiltration of the mandibular first molar: a prospective, randomized, double-blind study. J Endod 2015; 41: 1403-7.

10. Saatchi M, Khademi A, Baghaei B, Noormohammadi H. Effect of sodium bicarbonate-buffered lidocaine on the 
success of inferior alveolar nerve block for teeth with symptomatic irreversible pulpitis: a prospective, randomized double-blind study. J Endod 2015; 41: 33-5.

11. Comerci AW, Maller SC, Townsend RD, Teepe JD, Vandewalle KS. Effect of a new local anesthetic buffering device on pain reduction during nerve block injections. Gen Dent 2015; 63: 74-8.

12. Malamed SF, Tavana S, Falkel M. Faster onset and more comfortable injection with alkalinized $2 \%$ lidocaine with epinephrine 1:100,000. Compend Contin Educ Dent 2013; 34 Spec No 1: 10-20.

13. Malamed SF, Falkel M. Buffered local anaesthetics: the importance of ph and co2. SAAD Dig 2013; 29: 9-17.

14. Malamed SF, Falkel M. Advances in local anesthetics: $\mathrm{pH}$ buffering and dissolved $\mathrm{CO}_{2}$. Dent Today 2012; 31: 88-93; quiz 94-5.

15. Kashyap VM, Desai R, Reddy PB, Menon S. Effect of alkalinisation of lignocaine for intraoral nerve block on pain during injection, and speed of onset of anaesthesia. Br J Oral Maxillofac Surg 2011; 49: e72-5.

16. Kattan S, Lee SM, Hersh EV, Karabucak B. Do buffered local anesthetics provide more successful anesthesia than nonbuffered solutions in patients with pulpally involved teeth requiring dental therapy?: a systematic review. J Am Dent Assoc 2019; 150: 165-77.

17. Aulestia-Viera PV, Braga MM, Borsatti MA. The effect of adjusting the $\mathrm{pH}$ of local anaesthetics in dentistry: a systematic review and meta-analysis. Int Endod J 2018; 51: $862-76$.

18. Guo J, Yin K, Roges R, Enciso R. Efficacy of sodium bicarbonate buffered versus non-buffered lidocaine with epinephrine in inferior alveolar nerve block: a meta-analysis. J Dent Anesth Pain Med 2018; 18: 129-42.

19. Senthoor P, Janani K, Ravindran C. A prospective, randomized double-blinded study to evaluate the efficacy of buffered local anesthetics in infected and inflamed pulp and periapical tissues. J Maxillofac Oral Surg 2020; 19: 246-50.

20. Warren VT, Fisher AG, Rivera EM, Saha PT, Turner B, Reside G, et al. Buffered 1\% lidocaine with epinephrine is as effective as non-buffered $2 \%$ lidocaine with epinephrine for mandibular nerve block. J Oral Maxillofac Surg 2017; 75: 1363-6.

21. Phero JA, Nelson B, Davis B, Dunlop N, Phillips C, Reside $G$, et al. Buffered versus non-buffered lidocaine with epinephrine for mandibular nerve block: Clinical outcomes. J Oral Maxillofac Surg 2017; 75: 688-93.

22. Meincken M, Norman C, Arevalo O, Saman DM, Bejarano T. Anesthesia onset time and injection pain between buffered and unbuffered lidocaine used as local anesthetic for dental care in children. Pediatr Dent 2019; 41: 354-7.

23. M MA, Khatri A, Kalra N, Tyagi R, Khandelwal D. Pain perception and efficacy of local analgesia using $2 \%$ lignocaine, buffered lignocaine, and $4 \%$ articaine in pediatric dental procedures. J Dent Anesth Pain Med 2019; 19: 101-9.

24. Kurien RS, Goswami M, Singh S. Comparative evaluation of anesthetic efficacy of warm, buffered and conventional $2 \%$ lignocaine for the success of inferior alveolar nerve block (IANB) in mandibular primary molars: A randomized controlled clinical trial. J Dent Res Dent Clin Dent Prospects 2018; 12: 102-9.

25. Chopra R, Jindal G, Sachdev V, Sandhu M. Double-blind crossover study to compare pain experience during inferior alveolar nerve block administration using buffered two percent lidocaine in children. Pediatr Dent 2016; 38: 25-9.

26. Tavana S. Pain experiences in pediatric dental patients to buffered and conventional local anesthesia. UCSF [serial on the Internet]. 2013. Available from https://escholarship.org/uc/item/2fh4f5hg. 